\section{$E I P=2$ days}

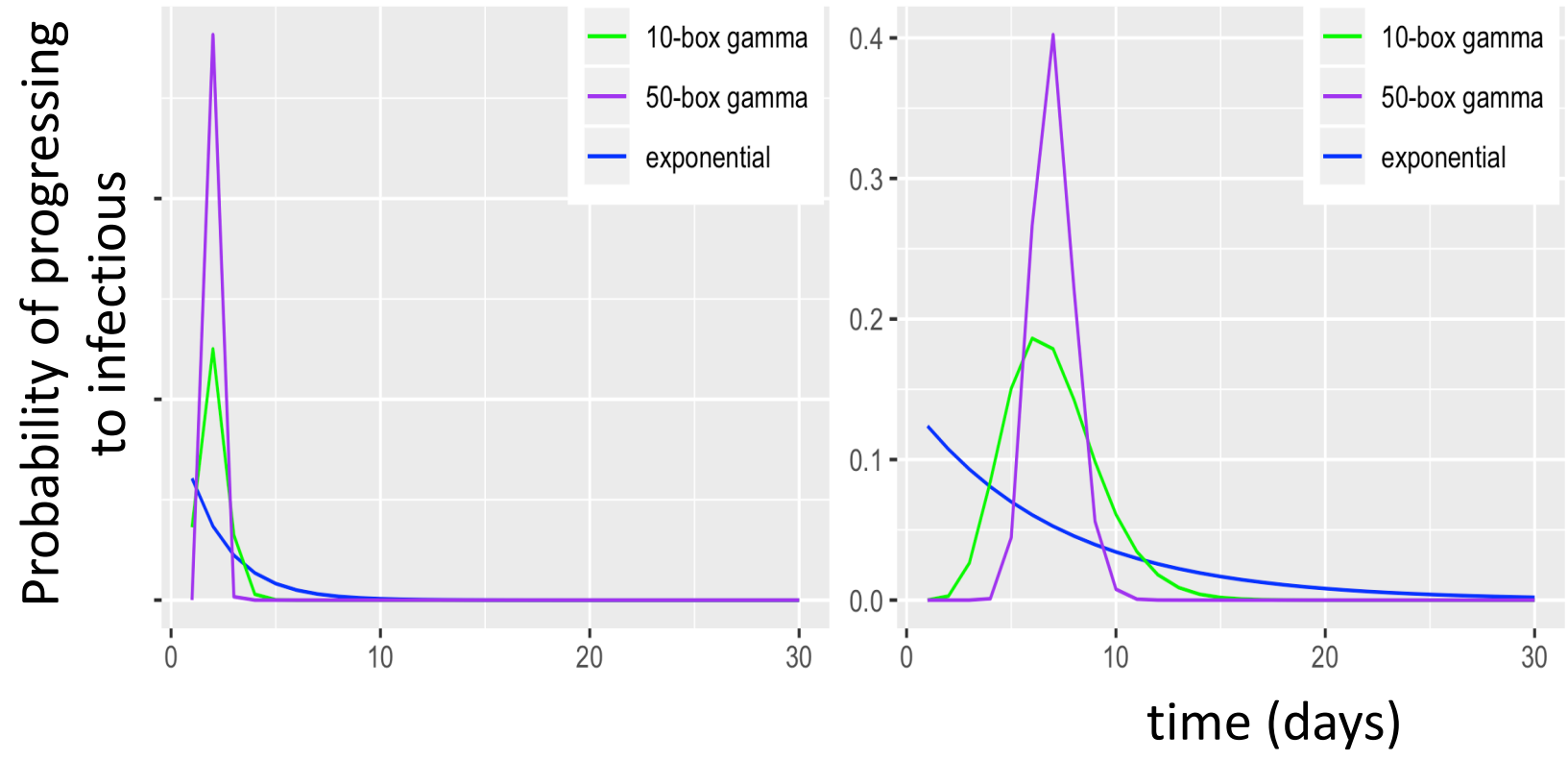

$E I P=10$ days

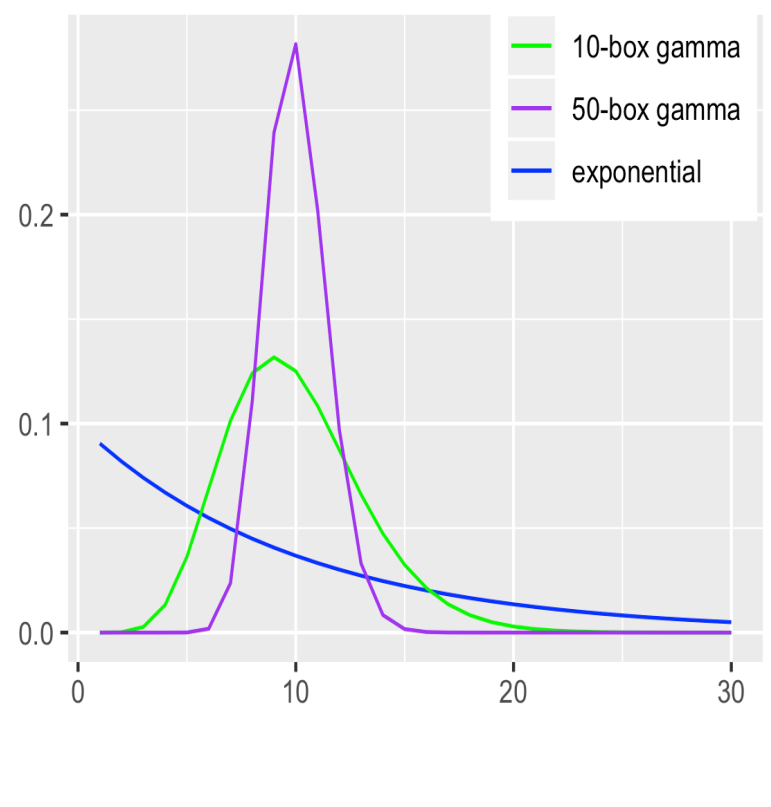

